\title{
Study on the Social and Economic Background for the Development of Traditional Settlements in South Hubei
}

\author{
Li Dong ${ }^{1, a^{*}}$, Chuan Sun ${ }^{2, b}$ and Yi Zheng ${ }^{2, c}$ \\ ${ }^{1}$ Wuhan University of Science and Technology, Wuhan, Hubei 430065, China \\ ${ }^{2}$ Hubei University of Education, Wuhan, Hubei 430205, China \\ a super_dongli@sina.com, b25885310@qq.com, ${ }^{\circ} 57653123 @ q q . c o m$
}

Keywords: Southern Hubei; Traditional settlement; Social economy; Production Mode

\begin{abstract}
The social and economic background for the development of traditional settlements in South Hubei comes from two main factors: mode of production for mountain agriculture and the economy partly composed of handicraft business. The former factor displays the features of mountain agriculture. Mainly focusing on traditional farming, this area has developed handicraft industry such as paper-making and tea-making, which forms part of the local economic composition. Meanwhile, the business-type settlements have developed in the place where both the water and the land transportation are convenient and where commerce and trade constitutes a large part of the economy.
\end{abstract}

\section{Introduction}

Southern Hubei lies in the intersection zone of Hubei, Jiangxi, and Hunan province, The climate is tepid and rainy. The terrain of South Hubei is characterized by mountainous areas in the north and low-lying lands in the south with hills representing the main geographic feature. Hills and basins interlace each other; rivers and river systems are numerous. Mountains and rivers separate the land for residence and tillage into parts, resulting into an original settlement keeps dividing into smaller ones during its expansion, which forms a concentric pattern centering the ancestral hall of a family or a clan in each settlement. It is this kind of geographic environment that facilitates the society and economy develop in the traditional settlements of South Hubei.

\section{Production Mode of Mountain Agriculture}

Features of Mountain Agriculture. Seen nationwide, rice-planting reflects the agricultural culture of South Hubei. Together with dry-land farming in Yellow River Basin, they are key elements of the production mode in China (Fig. 1).

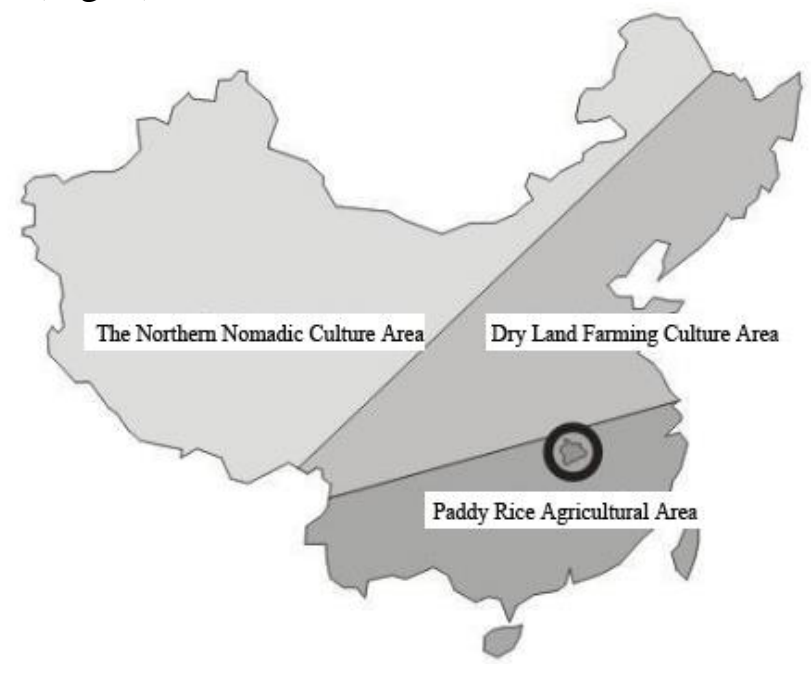

Figure 1. The geographical position relationship between south Hubei and the three cultural areas 
The cultural region developed from dry farming in Yellow River Basin which ranges from Qinling Mountains to the north of Huaihe River is the place where Xia, Shang and Zhou dynasties originate. The culture of these three dynasties has their own uniqueness and shows interconnected features inside, which altogether constitutes the main body of Chinese civilization and creates the propriety and music culture in Central Plains. In terms of main residents, the Huaxia People in Yellow River Basin is, in fact, the result of the migration, integration and marriages among many peoples. In terms of living patterns, Huaxia People lives in quadrangle-style buildings adopted by people in most regions which are based on ground buildings developed first from caves.

Located in the cultural region characterized by rice planting in Yangtze valley, south of Qinling Mountains and Huaihe River, South Hubei according to the categorization by Zhu Guangya belongs to the culture of Chu and Han in terms of the architectural style [1]. Compared with Central Plains, the geographical conditions here are much more complex and unpredictable. Mountain agriculture is a special ecological system featuring many mountains and few arable lands, sparse population, complex and various climates [2].Most parts of South Hubei are hilly areas with mountains, plains and lakes (Fig. 2). Although a mountainous area confines farming, it also brings a variety of food crops and other cash crops, thereby promoting a production mode and a life style prioritizing traditional farming supplemented by handicraft business.

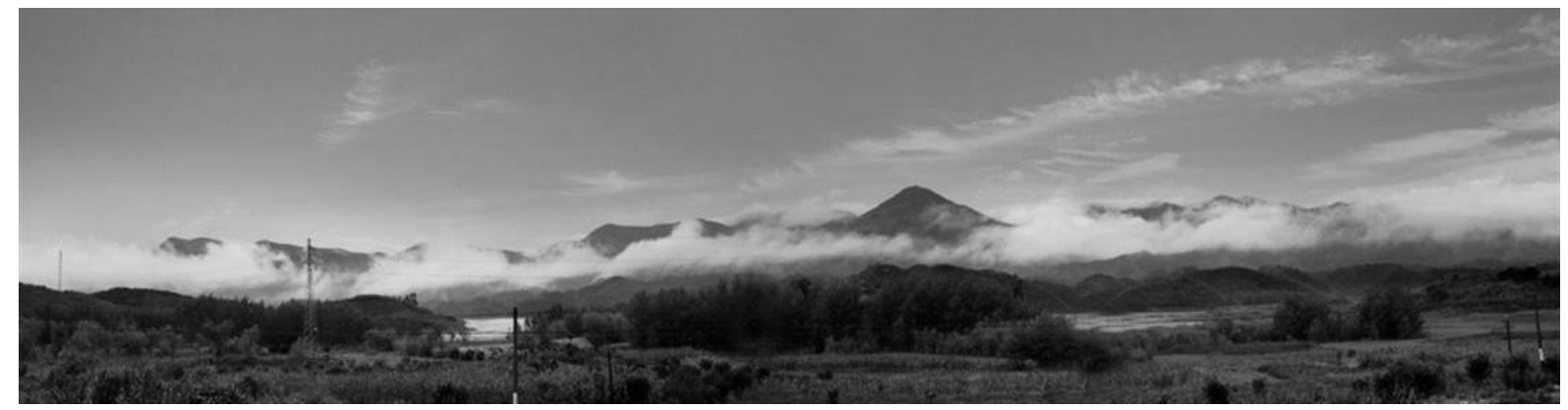

Figure 2. Low mountains and hills are the most common landscape in south Hubei

Advantages of Farming Culture. The production mode focusing on traditional farming creates the farming culture, which requires people to settle down so as to engage in agricultural activities. Irrigation has become an important aspect for farm work since water is indispensable to agricultural activities. Thus, some people have separated from farming and become specialized in the work of irrigation and water conservancy. The division of labor has facilitated the development productivity and the appearance of social stratum [3].This "fixed" mode of production and way of life have promoted a stable development of traditional clan-type villages. In this regard, it is believed that farming culture of the South is much more developed than nomadic culture and fishing-hunting culture of northern China, especially in facilitating social progress.

Mode of Settlement Development in South Hubei. The traditional settlement in South Hubei is clan-type with descendants of the same ancestor living in the same place. Most of these settlements gain development due to the migrants from Jiangxi Province in early days. Having settled down in South Hubei Province, the size of a clan keeps expanding with efforts of several generations and gradually forms what a settlement is like now. The characteristic of modern rural settlement is that people in the same village share the same surname such as the clan with all people surnamed Shu in Baoshan Village of Tongshan County and Cao in Shui Nanwan Village of Daye County [4].

The layout of villages where people live together by clans spreads from the inside out, which is the most distinct characteristic(Fig. 3). As a result, the building group is concentric as most old houses and ancestral houses are around the center surrounded by newly built houses, displaying a pattern of extending outwardly from the center. In the early stage of clan development, there is enough space for the expansion of villages. However, the coverage of buildings and farmlands goes up along with the increasing number of population. And the land is divided by hills and lakes, which constrains the 
development of settlements and the size of some villages. Thus, some clan-type villages takes on cell-like division with one into two, two into four... and occupy the whole left land[5].The spatial pattern of traditional settlements in South Hubei is concentric, which also reflects a hierarchical structure of the clan. Thus, a traditional settlement is not only limited to a geographical concept, but also it is a family community built on clan system and even a spiritual homeland bonding the whole clan.

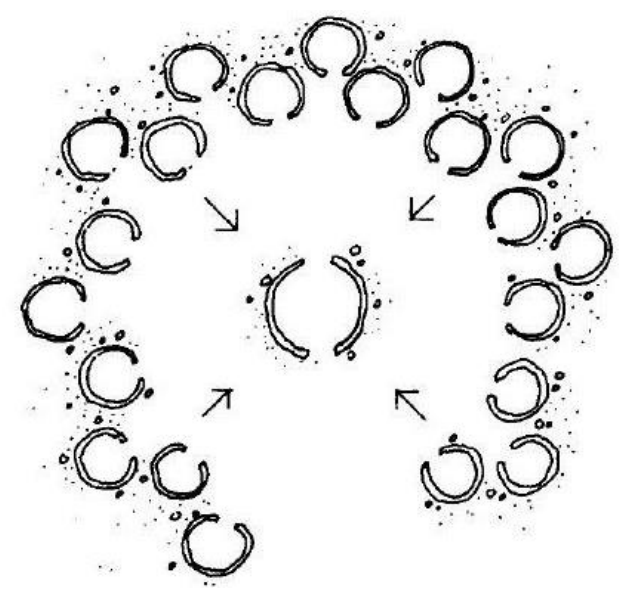

Figure 3. All houses open to a center

\section{Handicrafts as Part of the Agricultural Economy}

Handicrafts Fitting Local Conditions. Apart from farming, the social economy in South Hubei also develops in accordance with geographical constraints. The southeast Hubei has acid soils. Although there are many paddy fields, the productivity per unit is at a low level. Thus, the production mode is reflected by firs, phyllostachys pubescens, tea leaves, ramie and oil-seed rape [6], especially on the two most representative handicrafts: paper-making and tea-making.

South Hubei province abounds in phyllostachys pubescens and the paper-making with bamboo in this place can be dated back to Song dynasty when this technique was highly advanced at that time. General Annals of Hubei Province introduces the paper-making conditions of Puqi(now called Chibi city) cited from Collection of Essays Written in Study by Luyou, a famous poet in ancient days, among which, a sentence reads "paper produced in Puqi is a medium of knowledge delivery favored by senior scholars"[7]. County Annals of Puqi also records the prosperous development of paper-making and its approach in the reign of emperor Tongzhi in Qing dynasty. In the annals, it reads: "in south Dongshan village of the county, there is a place called Zhipeng with caves at the left border and spring water at the right border and there are forty households whose family name are Zheng living there; besides farming all the residents live on paper-making".

The Development of Commerce. Mild temperate, ample rainfall and fertile soil provide a favorable condition for growing tea, thus giving birth to the special tea culture in South Hubei.Yang Loudong of Chibi city is a commercial settlement developed from tea culture. Tea planting was started in Tang dynasty and the boom of tea-making industry in the reign of emperor Jiajing in Ming dynasty promoted the town, which gradually developed into a distributing center of tea business for hubei, jiangxi and Hunan provinces. After the First Opium War ends, Hankou became a trading port, attracting foreign businessmen from Russia, Japan, America and Germany who opened tea shops for purchasing and processing tea leaves and sold them all over the world. In the prime time of tea-making, there were five streets with over two hundred business shops and inns and forty thousand residents. Out of the demand for commercial circulation, the town extended and house were built along the river; people's daily activities such as communication and commerce all were carried out along the streets. 
Thus, besides a large number of clan-type settlements with all the people sharing one single surname within a settlement, there are also business-type settlements whose economic composition is mainly reflected by commerce and which accommodate many businessmen, workers and people engaged in other work.

\section{Conclusions}

In the early times of the feudal society, market towns grew due to regular village fairs. However, market towns develop for various reasons as the social economy increases and economic patterns become diverse after Qing dynasty. The distributing center of local goods and yearlong business activities are able to facilitate the development of market towns that are not planned on purpose but develop naturally by human gathering such as Xindian town of Chibi city expanding thanks to the convenient transportation and Baini of Chongyang county, Shi Menfan of Tongshan county; or some towns grow due to local products such as the tea- making and producing industry in Yang Loudong town of Chibi city. Some market towns exist among large-sized rural settlements so as to satisfy the demand for business such as the shops along the south bank in Baoshi village of Tongshan country and shops in the south of Shan Lirao village of Gaoqiao town in Xianan city.These commercial settlements that grow and boom depending on regional edges, distribute mostly in the regions where water transportation is much convenient. The spatial arrangement stresses patriarchal ethnics and follows the law of nature. Streets and houses connect closely and distribute along the changes of terrain, demonstrating a natural and harmonious scene of integrity.

\section{Acknowledgements}

This Project Supported by the National Social Science Foundation of China (Grant No. 15CG156), and the Young Teachers Program of Wuhan University of Science and Technology (Grant No. 250089).

\section{References}

[1] Zhu Guangya. Categorization and Genealogical Study of Chinese Ancient Architectural Districts [A]. Lu Yuanding, Panan. Building and Architectural Techniques of Traditional Chinese Dwellings [D]. Guangzhou: publishing house of SCUT. (2002), P7-8. (In Chinese)

[2] Shen Kangrong. Three-decade Development of Mountain Agriculture [M]. Beijing: China's Agricultural Science and Technology Press. (2008), P6. (In Chinese)

[3] Dai Zhizhong. Architectural Culture of Southwest China [M]. Hubei: Hubei Education Press.(2003), P74.(In Chinese)

[4] Li Xiaofeng, TanGangyi. Serial Books of Chinese Dwellings: Residents of Hunan and Hubei [M]. Beijing: China's Architectural Industry Press. (2009), P67. (In Chinese)

[5] Yang Guoan. Space and Order: Rural Ancestral Halls and Clans of Southeast Hubei after Ming-qiang Dynasties [J]. Editorial of Chinese Society and History.( 2008), No.01.(In Chinese)

[6] Li Huifang. Collection of Chinese Folk Traditions [M]. Lanzhou: Gansu People's Publishing House.(2004),P5.(In Chinese)

[7] Editorial Board for Local Chronicles of Hubei Province. Annals of Hubei [M]. Wuhan: Huibei People's Publishing House, (2010).(In Chinese)

[8] Wu Liangyong. Introduction to human settlement environment science [M]. Beijing: China's Architectural Industry Press. (2001). (In Chinese) 
[9] Huang Hao. Chinese traditional dwellings and culture [M]. Beijing: China's Architectural Industry Press. (1996). (In Chinese)

[10] Wang zhili. Chinese traditional local-style dwelling houses building [M]. Beijing: China's Architectural Industry Press. (1994). (In Chinese) 